\title{
A fogászati ellátás finanszírozása Németországban, az Egyesült Királyságban, Magyarországon és Lengyelországban
}

\author{
Marada Gyula dr. ${ }^{1,2}$ - Nagy Ákos dr. ${ }^{2}$ - Sebestyén Andor dr. ${ }^{1,3}$ \\ Endrei Dóra dr. ${ }^{1,4}$. Radnai Márta dr. ${ }^{2}$. Boncz Imre dr. ${ }^{1}$ \\ ${ }^{1}$ Pécsi Tudományegyetem, Egészségtudományi Kar, Egészségbiztosítási Intézet, Pécs \\ ${ }^{2}$ Pécsi Tudományegyetem, Fogorvos-tudományi Kar, Klinikai Központ, Fogászati és Szájsebészeti Klinika, Pécs \\ ${ }^{3}$ Országos Egészségbiztosítási Pénztár, Dél-dunántúli Területi Hivatal, Pécs \\ ${ }^{4}$ Pécsi Tudományegyetem, Klinikai Központ, Pécs
}

\begin{abstract}
Bevezetés: Az egészségügyi ellátások közül a fogászati beavatkozások száma a legmagasabb, és a finanszírozása is jelentős kiadásokat jelent. Célkitüzés: A vizsgálat célja négy európai ország egészségügyi rendszerének összehasonlítása a közösségi fogászati ellátás oldaláról. Módszer: A fogászati ellátásra fordított összegek és módszerek összehasonlításának alapját az egészségbiztosítók által biztosított adatok képezték. A vizsgálatban a következő indikátorokat értékelték: a közösségi fogászat arányszámait és a legfontosabb, szájegészséghez kapcsolódó indexeket. Az általános fogászati ellátások közül a prevenciós, konzerváló fogászati, endodonciai és szájsebészeti beavatkozásokat választották. Eredmények: Az egy aktív fogorvosra jutó lakosok száma Németországban (1247 lakos/fogorvos) a legkedvezőbb, míg Magyarországon (2020 lakos/fogorvos) a legrosszabb. A szájegészséghez kapcsolt indikátorok szignifikáns különbséget mutatnak a nyugat- és kelet-európai országok között. Ezzel ellentétben a teljes foghiányos lakosok százalékában nincsenek jelentős különbségek. A közösségi fogászati ellátás finanszírozására fordított összeg jelentősen magasabb Németországban és az Egyesült Királyságban. Következtetések: A fogászati ellátás finanszírozása jelentősen különbözik a vizsgált országokban. Orv. Hetil., 2016, 157(14), 547-553.
\end{abstract}

Kulcsszavak: közösségi fogászati ellátás, finanszírozás, egészségbiztosítási rendszer, bismarcki modell, beveridge-i modell

\section{Reimbursement of public dental care in Germany, the United Kingdom, Hungary and Poland}

\begin{abstract}
Introduction: Dental treatments have the highest rate among medical interventions and their reimbursement is also significant. Aim: The aim of the study was to compare the outcome of the reformed healthcare system process on public dental services in four European countries. Method: Assessment base for the comparison of reimbursement of dental treatments and dental fee schedules provided by the health insurance funds were used. The following indicators were examined: the ratio of public dental services and the main oral health indicators. Among dental fee schedules, reimbursement of general dental activity, prevention, operative dentistry, endodontic and oral surgery were selected. Results: The lowest value of population to active dentist ratio was found in Germany (population to active dentist ratio: 1247) and the highest in Hungary (population to active dentist ratio: 2020). Oral health indicators showed significant differences between the West-European and East-European countries. On the other hand, the ratio of completely edentulous people at the age of $65 \mathrm{yrs}$ did not show great variations. Reimbursement of public dental treatments indicated significantly higher value in Germany and the United Kingdom compared to the other countries. Conclusions: Reimbursement of public dental services varies considerably in the selected European countries.
\end{abstract}

Keywords: public dental service, reimbursement, health insurance system, Bismarck model, Beveridge model

Marada, Gy., Nagy, Á., Sebestyén, A., Endrei, D., Radnai, M., Boncz, I. [Reimbursement of public dental care in Germany, the United Kingdom, Hungary and Poland]. Orv. Hetil., 2016, 157(14), 547-553.

(Beérkezett: 2016. január 27.; elfogadva: 2016. február 18.) 
Minden európai ország rendelkezik önálló egészségügyi rendszerrel, de elsősorban történelmi okokra visszavezethetően különbség van közöttük, amit fooleg a strukturális felépítésben és az adminisztrációs különbségekben érhetünk tetten. Nyugat-Európában elsősorban két eltérô rendszer honosodott meg: a Bismarck-féle szolidaritáselvű társadalombiztosítási rendszer és a Beveridge-féle állami egészségügyi modell. Közép- és Kelet-Európában a szocialista rendszer az egészségügyben is erősen éreztette hatását. A korábbi rendszerekkel szakítva ezek az országok a Szemaskó-modellt adoptálták és a rendszerváltozásig fenn is tartották $[1,2]$.

Az egészségügyi rendszer célja, hogy növelje az egészségügyi ellátáshoz való hozzáférést, de a szúkös források miatt a döntéshozók feladata a forrásallokáció megfelelő kidolgozása [3]. Szinte minden országban javult a lakosság szájegészségi állapota az elmúlt évtizedekben, ám ennek ellenére a fogászati ellátás mindenhol az egészségpolitika fontos meghatározója. Számos országban a fogászati ellátás egyre inkább a magánfogorvosi ellátás felé tolódik el a központilag finanszírozott ellátással szemben. Azokban az országokban, ahol a szájegészséget meghatározó legfontosabb indikátorok, mint például a DMFT (Index of Decayed, Missing, Filled Teeth - a szuvas, hiányzó és tömött fogak számát jelző index) és parodontológiai indexek a lakosság megfelelő egészségi állapotát mutatják, az ellátásban inkább a közösségi ellátási forma kerül előtérbe az egyéni ellátással szemben [4]. Elsődleges feladatuk a különböző prevenciós stratégiák kidolgozása és a szűrőhálózat kiépítése. Azokban az országokban azonban, ahol a lakosság túlnyomó többségénél a mutatók nem ilyen kedvezőek, a közösségi ellátás során nemcsak a megelőzés a feladat, hanem biztosítani kell a minél nagyobb arányú hozzáférést a különböző ellátási formákhoz is [5-7].

A fogászati ellátásra fordított összeg szinte minden országban folyamatosan növekszik, de a finanszírozási formákban jelentős különbségek mutatkoznak [8-11].
A dolgozat célja, hogy bemutassa a fogászati ellátás közösségi finanszírozási formáit két közép-európai és két nyugat-európai ország példáján keresztül, a legfontosabb, szájegészséghez kapcsolódó indexek és egészségpolitikai mutatószámok segítségével (1. táblázat).

\section{Módszer}

A nyugat-európai országok közül Németországot és az Egyesült Királyságot választottuk, mert az ezekben az országokban létrehozott eltérő egészségügyi rendszereket tekinti a legtöbb európai ország alapmodellként. A közép-európai országok közül pedig hazánk mellett a lengyel modell elemzését végeztük el. Mindegyik ország egészségügyi rendszerének részletes bemutatása és elemzése már számos közleményben megjelent, így ezekból jelen dolgozatban csak a fogászati ellátás szempontjából lényeges területeket emeljük ki [12-17].

A vizsgálat alapját az EU (European Union) és az OECD (Organization for Economic Co-operation and Development) éves jelentései képezik [18]. Ezek mellett azt az EU által kibocsátott, a fogászati ellátás rendszereivel foglalkozó kézikönyvet is felhasználtuk, amely részletes információt szolgáltat többek között 32 európai ország fogászati ellátási rendszeréről, az ellátás szabályozásáról, valamint a képzés sajátosságairól. Az egyes beavatkozások finanszírozási értékének összehasonlításához az egészségbiztosítók által közzétett adatok szolgáltattak információt [19-22].

A vizsgálatban a következő indikátorokat hasonlítottuk össze: az aktív fogorvosok aránya, DMFT-index 12 éves korban, nulla DMFT-index aránya a 12 éves korcsoportban és a teljesen fogatlan lakosok aránya a lakosság körében.

A DMFT-indexet már több mint 70 éve alkalmazzuk világszerte a caries és fogászati epidemiológiai vizsgálatokban. Az indexet a maradó fogazat esetében alkalmaz-

1. táblázat |Az egészségügyi rendszer fő jellemzői Németországban, az Egyesült Királyságban, Magyarországon és Lengyelországban

\begin{tabular}{|c|c|c|c|c|}
\hline & Németország & Egyesült Királyság & Magyarország & Lengyelország \\
\hline Egészségügyi rendszer & Bismarck & Beveridge & Bismarck & Bismarck \\
\hline GDP per capita & $28,314 €$ & $29,052 €$ & $15,840 €$ & $13,995 €$ \\
\hline $\begin{array}{l}\text { Egészségügyi kiadások } \\
\text { (GDP \%-a) }\end{array}$ & 10,9 & 8,3 & 4,9 & 6,2 \\
\hline Finanszírozók száma & 132 Krankenkasse & 1 NHS & $1 \mathrm{OEP}$ & $1 \mathrm{NFZ}$ \\
\hline $\begin{array}{l}\text { Egy fogorvosra jutó } \\
\text { lakosok száma }\end{array}$ & 1247 & 1974 & 2020 & 1752 \\
\hline Évente végző fogorvosok & 1539 & 844 & 210 & 809 \\
\hline Fogászati ellátást nyújtók & Magán/közösségi & Magán/közösségi & Magán/közösségi & Magán/közösségi \\
\hline Nem finanszírozott & $\begin{array}{l}\text { Egyes anyagok (például } \\
\text { aranyötvözet, cirkónia) }\end{array}$ & $\begin{array}{l}\text { Kozmetikai fogászati } \\
\text { beavatkozások }\end{array}$ & $\begin{array}{l}\text { Rögzített fogpótlás 18-62 } \\
\text { év között, fogászati } \\
\text { implantátum }\end{array}$ & $\begin{array}{l}\text { Néhány anyag, mint } \\
\text { például fényre kötő } \\
\text { kompozit, aranyötvözet }\end{array}$ \\
\hline $\begin{array}{l}\text { Közösségi ellátás } \\
\text { finanszírozásának alapja }\end{array}$ & $\begin{array}{l}\text { Beavatkozásalapú } \\
\text { elszámolás }\end{array}$ & Kezelésalapú elszámolás & $\begin{array}{l}\text { Beavatkozásalapú } \\
\text { elszámolás }\end{array}$ & $\begin{array}{l}\text { Beavatkozásalapú } \\
\text { elszámolás }\end{array}$ \\
\hline
\end{tabular}


zuk, ahol a szuvas (decayed, D), a hiányzó (missing, M) és a tömött (filled, F) fogak számát adjuk össze, és az értéke egy vizsgált egyén esetén 0 és 28 vagy 32 között lehet, attól függően, hogy a bölcsességfogakat számítjuk vagy sem. Részletesebb adatot kapunk, ha a fogakat tovább bontjuk fogfelszínekre (DMFS). Ilyenkor a vizsgált egyén értékei 0 és 128 vagy 148 közötti lehet. A maradó fogak mellett létezik az indexnek egy tejfogazatra adaptált változata is (dmfs) [23]. A finanszírozási adatokból az általános fogászati beavatkozások, a konzerváló fogászat, endodoncia és szájsebészet szakirányokat határoztuk meg.

\section{Eredmények}

\section{Németország}

Németországban a fogászati ellátást döntően magánfogorvosok végzik és az ellátás finanszírozása a biztosítók által történik. Számos beavatkozás támogatott, de a támogatáson felüli összeget vagy kiegészítő biztosítással tudja fedezni a páciens, vagy saját magának kell azt állni. A biztosított támogatással tud igénybe venni olyan rutinbeavatkozásokat, mint a szájhigiénés ellátás, fogeltávolítás, amalgám- vagy esztétikus tömés, gyökérkezelés, nem sebészi parodontológiai ellátás vagy fogászati röntgenfelvétel készítése. A fogpótlások készítését meghatározott százalékig támogatják a biztosítók, de ezt több tényező, például a páciens fogazati állapota is befolyásolhatja. A nagyobb költséggel járó fogászati beavatkozásokat, mint például rögzített és kivehető fogpótlások, fogszabályozó kezelések, a biztosítók előzetesen elkészített és jóváhagyott kezelési és költségterv („Heil- und Kostenplan”) alapján támogatják. Vannak olyan beavatkozások is, amelyeket egyáltalán nem lehet támogatott formában igénybe venni. Ilyen például a betétek készítése vagy a fogászati implantátum beültetése. A német kormány a fogászati ellátásra fordítható összeget is meghatározza. Amennyiben a fogorvosok által végzett támogatott ellátások ezt az összeghatárt meghaladják, az egyes ellátások támogatásának mértéke is csökken.

A német finanszírozási rendszer sajátossága, hogy egy szorzó faktort alkalmaz a költségek számításához. Minden beavatkozáshoz a biztosítók egy pontértéket rendelnek, hasonlóan a magyar finanszírozási rendszerhez. Majd a beavatkozáshoz rendelt pontértéket egy meghatározott szorzóval növelik. A szorzó a beavatkozás bonyolultságát és a ráfordított időt tükrözi. Így a bonyolultabb és több időt igénybe vevő beavatkozások pontjait 3,5-del, míg az átlagos időráfordítást igénylő beavatkozások pontjait 2,3-del szorozzák. 2012-ben 5,62 € volt egy pont összegben kifejezett értéke. Ezenfelül a rendelők további költségeket is jelenthetnek, mint például a felhasznált lenyomatanyag mennyiségét.

Németországban 2008-ban hozzávetőlegesen 63000 általános fogászati praxis múködött. Ezzel ellentétben a közösségi ellátóhelyek száma csak mintegy 450 volt. Az egyetemeken közel 2000 fogorvost alkalmaztak fóállásban. 2008-ban 1247 lakosra jutott egy aktív fogorvos. Németország a GDP-nek 0,8\%-át fordította fogászati kezelések finanszírozására (2004).

A DMFT-index átlaga 12 éves korban 0,7 volt, míg ugyanezen korcsoport 70,1\%-a rendelkezett 0-s DMFTértékkel (2005). A lakosság 22,6\%-a volt 65 éves korában teljesen fogatlan [24].

\section{Egyesült Királyság}

Az Egyesült Királyságban a fogászati ellátást elsősorban az NHS-sel (National Health System) szerződött magánfogorvosok látják el. 2006. április 1-jétől az elszámolási rendszer megváltozott. A korábbi, elsősorban beavatkozásonkénti elszámolást egy kezelésalapú rendszer váltotta fel (UDA rendszer, vagyis Units of Dental Activity) [25].

AZ UDA-rendszer hasonló a sok országban üzemeltetett pontrendszerhez. A különbség az, hogy itt az elszámolás alapját nem az egyes beavatkozások képezik, hanem az egész kezelési tervben szereplő ellátás. Minden kezelés és a hozzá rendelt finanszírozási egység, a komplexitásától függően súlyszámot kap, ami alapján az ellátást egy finanszírozási kategóriába vagy sávba sorolják.

A finanszírozási egység számszerüsített értéke nem azonos, abban területenkénti eltérések figyelhetők meg. $\mathrm{Az}$ adott terület finanszírozási egységének értékét a helyi NHS-szervezetek határozzák meg a fogorvosok bevonásával. Átlagban egy egység 15-25 £ közötti térítési díjat jelent a fogorvos számára. Az „egyszerúbb” fogászati ellátások, mint például a betegvizsgálat, röntgenfelvétel készítése, szájhigiénés tanácsadás és kezelés, 1 UDAegységet jelent. Ha ennél összetettebb kezelést hajt végre egy fogorvos, mint például egy borítókorona elkészítése, az 12 UDA-egységnek felel meg. Viszont ez független a készített fogmúvek számától, csupán egy vagy akár 10 elkészülő pótlás esetén is ugyanaz a finanszírozás. Az UDA-rendszer azt is jelenti, hogy mindig a magasabb szintú beavatkozást tekintik az elszámolás alapjának. A fogorvosnak egyfajta garanciát is vállalnia kell az elvégzett kezelésekre, hiszen hasonló finanszírozási sávba eső kezelés két hónapon belül nem számolható el. Járulékos költségek elszámolására nincs lehetőség, a finanszírozás magában foglalja a labor- és technikai díjakat is (2. táblázat).

Az Egyesült Királyságban 2008-ban a magánfogorvosi praxisok becsült száma 24000 volt. További 1800 közösségi finanszírozású ellátóhely üzemelt és közel 2400 fogorvos dolgozott egyetemeken és kórházakban. Szintén ebben az évben 1976 lakosra jutott egy fogorvos. Fogászati ellátás finanszírozására 2004-ben a GDP 0,6\%át fordították.

2005-ben a DMFT-index a 12 éves korcsoportban 0,8 volt, és ugyanezen a korcsoportnak $62 \%$-a rendelkezett nullás indexértékkel. A 65 éves lakosok 36\%-a teljesen fogatlan (3. táblázat) [23]. 
2. táblázat $\mid$ Az Egyesült Királyság-beli UDA finanszírozási rendszer sávjainak összefoglalása

\begin{tabular}{|c|c|c|}
\hline Sávok & Súlyszám & Példa \\
\hline Sáv 1 & 1 & $\begin{array}{l}\text { - Klinikai vizsgálat } \\
\text { - Röntgenfelvétel készítése } \\
\text { - Fogkő-eltávolítás } \\
\text { - Prevenciós beavatkozások (például } \\
\text { barázdazárás) }\end{array}$ \\
\hline Sáv 2 & 3 & $\begin{array}{l}\text { - Parodontitis sebészi és nem sebészi kezelése } \\
\text { - Tömések } \\
\text { - Gyökérkezelés } \\
\text { - Fogeltávolítás }\end{array}$ \\
\hline Sáv 3 & 12 & $\begin{array}{l}\text { - Héj } \\
\text { - Betétek készítése } \\
\text { - Koronák } \\
\text { - Hidak } \\
\text { - Fogsorok }\end{array}$ \\
\hline
\end{tabular}

3. táblázat |A legfontosabb szájegészségi indikátorok összefoglalása

\begin{tabular}{|c|c|c|c|c|c|}
\hline & $\begin{array}{l}\text { Egy } \\
\text { fogor- } \\
\text { vosra } \\
\text { jutó } \\
\text { lakosok } \\
\text { száma }\end{array}$ & $\begin{array}{l}\text { DMFT } \\
12 \text { éves } \\
\text { korban }\end{array}$ & $\begin{array}{l}\text { Nulla } \\
\text { DMFT- } \\
\text { index- } \\
\text { szel } \\
\text { rendel- } \\
\text { kező } \\
12 \text { éves } \\
\text { korú } \\
\text { gyerme- } \\
\text { kek } \\
\text { aránya }\end{array}$ & $\begin{array}{l}\text { DMFT } \\
\text { a } 35-44 \\
\text { éves } \\
\text { korcso- } \\
\text { portban }\end{array}$ & $\begin{array}{l}65 \\
\text { évesen } \\
\text { teljesen } \\
\text { fogatla- } \\
\text { nok } \\
\text { aránya }\end{array}$ \\
\hline Németország & 1247 & 0,7 & $70,1 \%$ & 16,3 & $22,6 \%$ \\
\hline Egyesült Királyság & 1976 & 0,8 & $62,0 \%$ & 19 & $36,0 \%$ \\
\hline Magyarország & 2020 & 3,3 & $16,0 \%$ & 15 & $30,0 \%$ \\
\hline Lengyelország & 1752 & 3,1 & $19,3 \%$ & 19,2 & $42,0 \%$ \\
\hline
\end{tabular}

\section{Magyarország}

A fogászati ellátást Magyarországon a magán- és az OEP-pel (Országos Egészségbiztosítási Pénztár) szerződött fogászati alap- és szakellátást nyújtó szolgáltatók biztosítják. A finanszírozott szolgáltatóknál a havi finanszírozás fix díjból és teljesítménydíjból tevődik össze. Az OEP által finanszírozott fogászati alapellátás felnőtt, vegyes, valamint gyermek és ifjúsági körzetekben valósul meg, ahol a fix díjat a praxis létszámától függően degresszióval korrigált korcsoportos (0-18 év, 19-62 év és 62 év felettiek) pontszáma képezi. A finanszírozott fogászati szakelláás röntgen, fogszabályozás, szájsebészet, paradontológia, valamint egyetemi szakellátás szintjein történik, ahol a havi fix díj nagyságát jogszabály határozza meg. A teljesítmény díjazása a jelentett beavatkozásokhoz tartozó német típusú pontrendszer alapján történik, zárt kasszából.

A fogászati vizsgálat, fogmegtartó kezelések (például tömés készítése, gyökérkezelés és tömés), parodontológiai kezelések, fogeltávolítás és fogkő-eltávolítás térítésmentes a páciens életkorától függetlenül [26]. A többi beavatkozást - mint például a rögzített fogpótlások, fogászati implantátumok, rögzített fogszabályozó készülékek készítése - a páciensek csak térítés ellenében vehetik igénybe [27]. Az aktív keresők a 19-62 év közötti korcsoportban a fogorvosi ellátás és a technikai díj 100\%-át kötelesek téríteni. A 18 év alattiak, a 62 év felettiek, a terhesek és a kevesebb mint 3 hónapja szültek a fogorvosi díj megfizetése alól mentesülnek, és a technikai díj is co-payment rendszerben valósul meg.

Hazánkban 2008-ban 4040 általános fogorvosi praxis múködött. Ezzel szemben az állami fenntartású ellátóhelyek száma körülbelül 40 volt. A vizsgált időszakban 240 fogorvos dolgozott egyetemeken vagy kórházakban. Egy fogorvosra 2020 lakos jutott. Magyarországon 2007-ben a GDP 0,08\%-át fordították fogászati ellátásra (1. ábra).

A szájegészséget mutató indikátorok közül a DMFTindex a 12 éves korcsoportban 3,3 volt (2001), és ugyanennek a csoportnak csak $16 \%$-a ért el nullás értéket. A lakosság 30\%-a 65 éves korára vált teljesen fogatlanná 2006-ban (3. táblázat) [23].

\section{Lengyelország}

Lengyelországban a fogászati ellátást magánfogorvosok látják el és a finanszírozást a Nemzeti Egészségbiztosítótól (Narodowy Fundusz Zdrowia - NFZ) kapják. A biztosítottak jogosultak a legtöbb fogászati ellátás igénybevételére ingyenesen, akár szájsebészeti beavatkozásokat is beleértve, a biztosító és a kamara által közösen meghatározott fogászati anyagok felhasználásával. Az NFZbiztosítottak csak az illetékes minisztérium által meghatározott beavatkozások listájában szereplő ellátási formákat vehetik igénybe teljesen díjmentesen. A listában nem szereplő beavatkozásokért fizetniük kell. A térítésmentesen igénybe vehető ellátások listája nem egységes, korcsoportonként változik annak tartalma. A gyermekek és fiatalkorúak számára biztosított ellátások sora lényegesen bővebb.

Lengyelországban 2008-ban 20240 általános fogászati praxis múk ödött, és körülbelül 1450 volt az állami

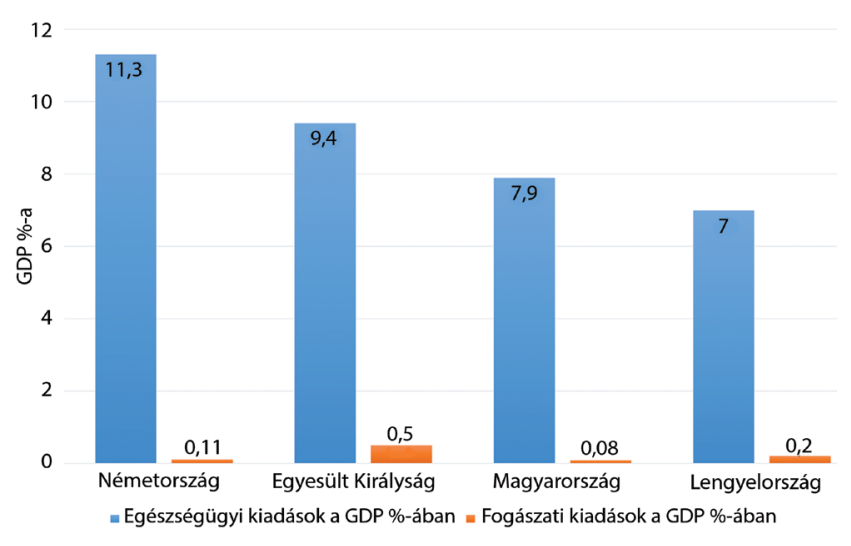

1. ábra $\quad$ Az egészségügyi és fogászati kiadások az egyes országokban a GDP százalékában kifejezve (forrás: OECD, 2011) 
fenntartású rendelő. Közülük sok egyetemek, kórházak és katonai központok területén található. 2008-ban 1752 betegre jutott egy fogorvos. Fogászati ellátásra 2004-ben a GDP 0,2\%-át költötték.
A DMFT-index a 12 éves gyermekeket vizsgálva 3,1 átlagértéket hozott 2007-ben, és 19,2\%-uk ért el nulla értéket. 65 éves korban a lakosság 42\%-át találták teljesen fogatlannak 2005-ben (3. táblázat) [23].

4. táblázat $\mid$ Egyes fogászati kezelések térítési díjainak összehasonlítása Németországban, Angliában, Magyarországon és Lengyelországban ( ${ }^{\star} 1$ € = 296,91 Ft, $\mathrm{MNB}, 2014$. 01. 01.; ${ }^{*} 1 £=356,76 \mathrm{Ft}, \mathrm{MNB}, 2014$. 01. 01.; ${ }^{* *} 1$ pont $=2,093 \mathrm{Ft}, 2013$. december; ${ }^{* * *} 1$ pont $=1,08 \mathrm{zt}(0,25 €), 2013$. december)

\begin{tabular}{|c|c|c|c|c|c|c|c|c|}
\hline \multirow[t]{2}{*}{ Kezelés } & \multicolumn{2}{|c|}{ Németország } & \multicolumn{2}{|c|}{ Egyesült Királyság } & \multicolumn{2}{|c|}{ Magyarország } & \multicolumn{2}{|c|}{ Lengyelország } \\
\hline & $\begin{array}{l}\text { Térítési díj } \\
(€)\end{array}$ & $\begin{array}{l}\text { Forint- } \\
\text { ban* }\end{array}$ & $\begin{array}{l}\text { Sávhoz } \\
\text { tartozó } \\
£ \text { érték }\end{array}$ & $\begin{array}{l}\text { Forint- } \\
\text { ban** }\end{array}$ & Pont & $\begin{array}{l}\text { Forint- } \\
\text { ban*** }\end{array}$ & Pont & $\begin{array}{l}\text { Forint- } \\
\text { ban**** }\end{array}$ \\
\hline \multicolumn{9}{|l|}{ Általános fogászat és prevenció } \\
\hline $\begin{array}{l}\text { Szájvizsgálat (fogászati és parodontológiai } \\
\text { státusz) }\end{array}$ & 12,94 & 3842 & 18 & 6421 & 180 & 376,74 & 22 & 1633 \\
\hline Tanulmányi minta készítése & 15,52 & 4608 & 18 & 6421 & 0 & 0 & 11 & 816 \\
\hline Fogvitalitás-vizsgálat & 6,47 & 1921 & 18 & 6421 & 0 & 0 & 2 & 148 \\
\hline Intraoralis érzéstelenítés & 3,88 & 1152 & 18 & 6421 & 50 & 104,65 & 20 & 1484 \\
\hline Szájhigiénés tanácsadás ( 25 perc) & 25,87 & 7681 & 18 & 6421 & 50 & 104,65 & 11 & 816 \\
\hline Helyi fluoridálás & 6,47 & 192 & 18 & 6421 & 120 & 251,16 & 5 & 371 \\
\hline Barázdazárás foganként & 11,64 & 3456 & 18 & 6421 & 300 & 627,9 & 11 & 816 \\
\hline \multicolumn{9}{|l|}{ Konzerváló fogászat és endodontia } \\
\hline Plasztikus tömés egy felszínre & 27,55 & 8179 & 49 & 17481 & 600 & 1255,8 & & \\
\hline Kompozit tömés egy felszínre & 68,17 & 20240 & 49 & 17481 & 700 & 1465,1 & $\begin{array}{l}38 \text { (csak } \\
\text { önkötő) }\end{array}$ & 2820 \\
\hline Plasztikus tömés két felszínre & 31,3 & 9293 & 49 & 17481 & 850 & 1779,05 & & \\
\hline Kompozit tömés két felszínre & 71,92 & 21353 & 49 & 17481 & 950 & 1988,35 & $\begin{array}{l}43 \text { (csak } \\
\text { önkötő) }\end{array}$ & 3192 \\
\hline Inlay egy felszín & 147,6 & 43823 & 214 & 76346 & 600 & 1255,8 & 8 & 594 \\
\hline Inlay több felszín & 175,41 & 52080 & 214 & 76346 & 600 & 1255,8 & 75 & 5567 \\
\hline Fogtrepanáció & 8,41 & 2497 & 21,6 & 7706 & 100 & 209,3 & & \\
\hline Gyökértömés csatornánként & 33,37 & 9907 & 49 & 17481 & 1200 & 2511,6 & & \\
\hline \multicolumn{9}{|l|}{ Szájsebészet } \\
\hline Egygyökerú fog eltávolítása & 9,05 & 2687 & 49 & 17481 & 100 & 209,3 & 20 & 1484 \\
\hline Többgyökerű fog eltávolítása & 14,23 & 4225 & 49 & 17481 & 100 & 209,3 & 30 & 2227 \\
\hline Fog mütéti eltávolítása & 45,27 & 13441 & 49 & 17481 & 600 & 1255,8 & 47 & 3489 \\
\hline Impactalt vagy retinealt fog eltávolítása & 69,85 & 20739 & 49 & 17481 & 1200 & 2511,6 & 100 & 7423 \\
\hline Sinuszárás & 47,86 & 14210 & 49 & 17481 & 1500 & 3139,5 & 156 & 11579 \\
\hline Gyökércsúcs-reszekció & 59,5 & 17666 & 49 & 17481 & 1250 & 2616,25 & 0 & \\
\hline Cisztamütét & 64,68 & 19204 & 49 & 17481 & 2000 & 4186 & 100 & 7423 \\
\hline \multicolumn{9}{|l|}{ Parodontológia } \\
\hline Parodontalis status & 20,7 & 6146 & 18 & 6421 & 250 & 523,25 & 0 & 0 \\
\hline Parodontalis mütét & 16,82 & 4994 & 49 & 17481 & 600 & 1255,8 & 0 & 0 \\
\hline Nyitott curettage & 23,28 & 6912 & 49 & 17481 & 600 & 1255,8 & 22 & 1632 \\
\hline \multicolumn{9}{|l|}{ Fogpótlástan } \\
\hline $\begin{array}{l}\text { Öntött korona készítése tangencionális } \\
\text { preparálással }\end{array}$ & 171,01 & 50774 & 214 & 76346 & 600 & 1255,8 & 0 & 0 \\
\hline $\begin{array}{l}\text { Öntött korona készítése vállas } \\
\text { preparálással }\end{array}$ & 217,06 & 64447 & 214 & 76346 & 800 & 1674,4 & 0 & 0 \\
\hline Teljes kivehető fogsor a mandibulán & 239,31 & 71053 & 214 & 76346 & 3000 & 6279 & 528 & 39192 \\
\hline Protetikai rehabilitáció & 944,3 & 280372 & 214 & 76346 & 14000 & 29302 & 0 & 0 \\
\hline
\end{tabular}




\section{A négy ország összehasonlitása}

Az egyes országok fogászati ellátásának finanszírozását a 4. táblázat alapján összehasonlítva azt a következtetést vonhatjuk le, hogy a különböző egészségügyi rendszerek eltérő ellátások felé próbálják a rendelkezésre álló forrásokat allokálni. Németországban, ahol a szájegészséggel összefüggő indikátorok jó egészségi állapotot mutatnak, elsősorban a prevencióra és a felvilágosításra fektetnek hangsúlyt. Az Egyesült Királyságban az UDA-rendszer megalkotásának is az volt az elsődleges célja, hogy javítsa a megelőző tevékenység hatékonyságát. Ennek kicsit ellentmond, hogy minden ezzel kapcsolatos tevékenység a legalacsonyabb finanszírozási sávba esik. Magyarországon és Lengyelországban számos beavatkozás, amelyek egyes protokollok részét képezik, külön nem számlázhatók a biztosítók felé. Ilyen például a tanulmányi minta készítése, a fogak vitalitásának vizsgálata, amelyek egyébként a betegvizsgálat és kezelési terv készítésének szerves részét képezik. Hasonlóan ehhez, részfolyamatok elszámolására sincs külön lehetőség, azok a kezelés végén kerülnek finanszírozásra. Ilyen például a rögzített fogpótlás készítése során vett lenyomat, harapásregisztrálás. Ez az elv mind a négy vizsgált országban azonos.

Ha a fogmegtartó kezeléseket vizsgáljuk, azt láthatjuk, hogy az ilyen jellegü beavatkozások mind a négy országban a finanszírozott ellátások kategóriájába esnek. Szinte minden országban különbséget tesznek azonban az alkalmazott tömőanyag kérdésében. Lengyelországban csak a plasztikus (amalgám, önkötő kompozit, üvegionomer) tömőanyag finanszírozott. A gyökérkezelések és tömések finanszírozása során a fogorvos az eset összetettségével (gyökércsatornák száma) arányos kompenzációban részesül. Az Egyesült Királyságban a gyökércsatorna bemenetének preparálása a sürgősségi beavatkozások közé került, és az 1,2-es szorzóval rendelkező sávba sorolták.

A szájsebészeti beavatkozások esetén nincs különbség Magyarországon és az Egyesült Királyságban a fogeltávolítást illetően, nem tesznek különbséget az egy- vagy a többgyökerü fogak között. Különbség van azonban a fogak hagyományos úton történő és a sebészi feltárással végzett beavatkozás között. Sebészi feltárással végzett eltávolításért Lengyelországban másfélszer, Németországban háromszor és Magyarországon hatszor magasabb a finanszírozási összeg, mint az egyszerú fogeltávolításért. Magyarország kivételével az impaktált fogak és az állcsontciszták eltávolítása ugyanazzal az értékkel finanszírozott. Hazánkban a cisztaeltávolító mútét a legmagasabb összeggel kompenzált szájsebészeti beavatkozás.

\section{Megbeszélés}

A fogászati ellátások közösségi finanszírozása különbözik a vizsgált országokban [28-30]. Alapvető különbség, hogy Magyarországon, Lengyelországban és Németországban elsősorban beavatkozásalapú elszámolási rend- szert alkalmaznak a biztosítók. Ezen három ország közül Németországban a legmagasabb a beavatkozások finanszírozásának átlagösszege, amely Lengyelországhoz képest háromszor, míg Magyarországhoz képest közel tízszer magasabb összeget jelent.

Az Egyesült Királyságban a jelenleg is múködő UDArendszert 2006-ban vezették be. Bevezetésének célja az volt, hogy a fogorvosokat a beavatkozás után járó finanszírozás helyett egy komplexebb ellátási forma felé irányítsák elsősorban prevenciós elveket szem előtt tartva. A fogorvosok képviselői a bevezetés óta számos aggályt és kételyt fogalmaztak meg, miszerint az új rendszer csak az elérni kívánt terápiás célt tartja szem előtt, viszont nem veszi figyelembe a fogorvosok és a páciensek érdekeit. Számos esetben a páciens „alulkezelt”, mert a fogorvos nem biztosítja a komplex (és leggyakrabban költséges) terápiát, még akkor sem, ha az klinikailag szükséges lenne. Az UDA-rendszerben az azonos sávba tartozó ellátások azonos összeggel kerülnek finanszírozásra. Ez nehézzé teszi a többi országgal való összehasonlítást, de ha a kezelések átlagos finanszírozási értékét nézzük, akkor az alig marad el a német értékektől. Szintén az UDArendszer sajátossága, hogy nagyon nem tesz különbséget a felhasznált anyagok között, és a fogorvos szabad döntésére bízza a választást. Mivel a finanszírozásban sem jelenik meg a különbség, így a felhasználó a legtöbb esetben az olcsóbb és alacsonyabb minőségi szintet képviselő termékeket részesíti előnyben.

A korábban Szemaskó-modellt követő két ország egészségbiztosítási rendszere manapság inkább a Bismarck-modellhez áll közelebb. Különbség, hogy míg a magyar rendszer erőteljesen centralizált, addig Lengyelországban 2003-tól a 16 regionális szervezet látja el az adminisztratív feladatokat.

Ha a finanszírozási összegeket tekintjük, akkor azok hazánkban a legalacsonyabbak, és Lengyelországban is csak kismértékben jobb az egyébként alulfinanszírozott ellátórendszer helyzete. Mindkét ország kormánya számos erőfeszítést tesz ennek kompenzálására, de a hátrányos helyzetból induló országokban ez jelenleg is komoly problémát jelent a szúkös források megfelelő allokációjával is.

Minden vizsgált ország egészségügyi rendszerének elsődleges feladata, hogy a lehető legmagasabb színvonalú ellátást biztosítsa a lakosság számára. A gazdasági egyenlőtlenségek ellenére azok az országok, amelyek GDP-jük magasabb százalékát tudják fogászati ellátásra fordítani, a közösségi ellátás szintjén nem tudnak magasabb minőségű szolgáltatást biztosítani. Magyarországon és Lengyelországban a szájegészséghez kapcsolódó indikátorok (DMFT-index a 12 éves korcsoportban és a nulla DMFTindexszel rendelkezők aránya ugyanebben az életkorban) a fiatalabb korcsoportokban rosszabb értékeket mutatnak a nyugati országok hasonló adataival összehasonlítva. Ez a különbség azonban a bevezetett prevenciós intézkedéseknek és a felvilágosító munkának köszönhetően folyamatosan csökken [31]. A teljesen fogatlan 
lakosság részaránya a 65 éves korcsoportban viszont nem mutat számottevő eltérést a vizsgált országokban.

A kelet- és közép-európai országok számára mindenképpen kihívást jelent egy olyan egészségügyi finanszírozási rendszernek a megalkotása, amely homogén modellként képes magába integrálni a régió szomszédos országai által is adoptált nyugat-európai modelleket. Mindezek mellett azonban figyelemmel kell lenniük a saját lakosságuk egyedi szükségleteire is, amely sok esetben nagyban eltér más nemzetek vagy kultúrák sajátosságaitól, és mindezeket figyelembe véve kell megfelelni a jövő kihívásainak is $[32,33]$.

Anyagi támogatás: A közlemény megírása anyagi támogatásban nem részesült.

Szerzôi munkamegosztás: M. Gy: A hipotézis kidolgozása, a kézirat megszövegezése. N. Á.: A hipotézis kidolgozása. S. A., B. I.: A hipotézis kidolgozása, adatok elemzése. E. D.: Az adatok elemzése, a kézirat korrekciója. R. M.: A hipotézis kidolgozása, a kézirat végső korrekciója. A cikk végleges változatát valamennyi szerző elolvasta és jóváhagyta.

Érdekeltségek: A szerzőknek nincsenek érdekeltségeik.

\section{Irodalom}

[1] Widström, E., Eaton, K. A., Borutta, A., et al.: Oral healthcare in transition in Eastern Europe. Br. Dent. J., 2001, 190(11), 580584 .

[2] McKee, M., Dubois, C. A.: Health systems in transition in Central and Eastern Europe. J. R. Coll. Physicians Edinb., 2004, 34(4), 305-312.

[3] Endrei, D., Zemplényi, A., Molics, B., et al.: The effect of performance-volume limit on the DRG based acute care hospital financing in Hungary. Health Policy, 2014, 115(2-3), 152-156.

[4] Boncz, I., Vajda, R., Agoston, I., et al.: Changes in the health status of the population of Central and Eastern European countries between 1990 and 2010. Eur. J. Health Econ., 2014 15(Suppl. 1), 137-141.

[5] Sebestyén, A., Dózsa, Cs., Bánóczy, J., et al.: Preventive oral health services in dental practices of Hungary. Oral Health Dental Manag. Black Sea Countries, 2008, 7(1), 24-30.

[6] Marada, G., Nagy, A., Benke, B., et al.: Health insurance financing of dental care in Hungary. [A fogászati ellátás egészségbiztosítási finanszírozása Magyarországon.] Fogorv. Sz., 2012, 105(1), 3-8. [Hungarian]

[7] Sebestyén, A., Boncz, I., Pál, M.: Preventive dental care in the south part of Transdanubium. [Fogászati preventív vizsgálatok a Dél-Dunántúlon.] Egészségügyi Menedzsment, 2002, 4(4),6165. [Hungarian]

[8] Davidson, T., Roblin, M., Hultin, M., et al.: Reimbursement systems influence prosthodontic treatment of adult patients. Acta Odontol. Scand., 2015, 73(6), 414-420.

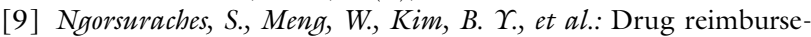
ment decision-making in Thailand, China, and South Korea. Value Health, 2012, 15(Suppl. 1), S120-S125.

[10] Tan, S. S., Redekop, W. K., Rutten, F. F.: Cost and prices of single dental fillings in Europe: a micro-costing study. Health Econ., 2008, 17(Suppl. 1), S83-S93.

[11] Lundqvist, M., Davidson, T., Ordell, S., et al.: Health economic analyses of domiciliary dental care and care at fixed clinics for elderly nursing home residents in Sweden. Community Dent. Health, 2015, 32(1), 39-43.

[12] Sagan, A., Panteli, D., Borkowski, W., et al.: Poland health system review. Health Syst. Transit., 2011, 13(8), 1-193.

[13] Gaál, P., Szigeti, S., Csere, M., et al.: Hungary health system review. Health Syst. Transit., 2011, 13(5), 1-266.

[14] Boyle, S.: United Kingdom (England): Health system review. Health Syst. Transit., 2011, 13(1), 1-483.

[15] Boncz, I., Sebestyén, A.: Financial deficits in the health services of the UK and Hungary. Lancet, 2006, 368(9539), 917-918.

[16] Boncz, I., Nagy, J., Sebestyén, A., et al.: Financing of health care services in Hungary. Eur. J. Health Econ., 2004, 5(3), 252-258.

[17] Endrei, D., Molics, B., Ágoston, I.: Multicriteria decision analysis in the reimbursement of new medical technologies: real-word experiences from Hungary. Value Health, 2014, 17(4), 487489.

[18] EU Manual of Dental Practice. http://www.eudental.eu/index. php? ID $=2740$

[19] What is included in each NHS dental band charge? http://www. nhs.uk/chq/Pages/nhs-dental-band-charges.aspx

[20] Gebüehrenordnung für Zahnärzte. http://www.bzaek.de/fileadmin/PDFs/goz/nov/gebuehrenordnung_fuer_zahnaerzte_2012_EN.pdf

[21] Code list of dental interventions. [A fogászati beavatkozások kódlistája.] http://www.oep.hu/data/cms993643/FOGASZATI_SZABALYKONYV_71_2011_NEFMI_R_OEP.pdf?query= fog $\%$ C3\%Alszat $\% 20 \mathrm{k} \% \mathrm{C} 3 \% \mathrm{~B} 3$ dlista [Hungarian]

[22] Zarządzenie Nr 3/2014/DSOZ Prezesa Narodowego Funduszu. http://www.nfz.gov.pl/new/?katnr=3\&dzialnr=12\&art $\mathrm{nr}=5902$ [Polish]

[23] Cappelli, D. P., Mobley, C. C.: Prevention in Clinical Oral Health Care. Mosby Elsevier, Philadelphia, 2007.

[24] Schützhold, S., Holtfreter, B., Hoffmann, T., et al.: Trends in dental health of 35- to 44-year-olds in West and East Germany after reunification. J. Public Health Dent., 2013, 73(1), 65-73.

[25] Harris, R., Mosedale, S., Garner, J., et al.: What factors influence the use of contracts in the context of NHS dental practice? A systematic review of theory and logic model. Soc. Sci. Med., 2014, $108,54-59$.

[26] Act 83 of the year 1997 on obligatory health insurance provision. [1997. évi LXXXIII. törvény a kötelező egészségbiztosítás ellátásairól.] http://net.jogtar.hu/jr/gen/hjegy_doc.cgi?docid= 99700083.TV [Hungarian]

[27] Government Order 284/1997. (XII. 23.) on tariff of health care services available in case of payment [284/1997. (XII. 23.) Korm. rendelet térítési díj ellenében igénybe vehető egyes egészségügyi szolgáltatások térítési díjáról.] http://net.jogtar.hu/jr/ gen/hjegy_doc.cgi?docid=99700284.KOR [Hungarian]

[28] Quiñonez, C., Grootendorst, P.: Equity in dental care among Canadian households. Int. J. Equity Health, 2011, 10, 14.

[29] Tchicaya, A., Lorentz, N.: Socioeconomic inequalities in the nonuse of dental care in Europe. Int. J. Equity Health, 2014, 13, 7. http://www.equityhealthj.com/content/13/1/7

[30] Bock, J. O., Matschinger, H., Brenner, H., et al.: Inequalities in out-of-pocket payments for health care services among elderly Germans - results of a population-based cross-sectional study. Int. J. Equity Health, 2014, 13, 3.

[31] Davis, E. E., Deinard, A. S., Maigga, E. W.: Doctor, my tooth hurts: the costs of incomplete dental care in the emergency room. J. Public Health Dent., 2010, 70(3), 205-210.

[32] Boncz, I., Evetovits, T., Dózsa, Cs., et al.: The Hungarian Care Managing Organization Pilot Program. Value Health Regional, 2015, 7, 27-33.

[33] Greenberg, D., Mohamed Ibrahim, M. I. B., Boncz, I.: What are the challenges in conducting cost-of-illness studies? Value Health Regional, 2014, 4, 115-116.

(Marada Gyula dr. MSc., Pécs, Dischka Győző u. 5., 7621 e-mail: marada.gyula@pte.hu) 